\title{
Underwater endoscopic mucosal resection for small rectal neuroendocrine tumors
}

\author{
Lara Meireles Azeredo COUTINHO', Luciano LENZ1,2, Fabio S KAWAGUTI'1,2, Bruno Costa MARTINS ${ }^{1,2}$,

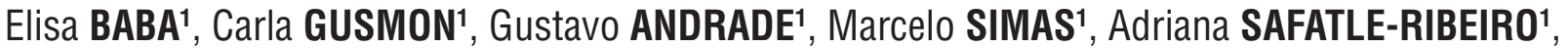 \\ Fauze MALUF-FILHO' ${ }^{1}$, Rodrigo RODRIGUES ${ }^{2}$ and Ulysses RIBEIRO JR ${ }^{1}$
}

Received: 24 November 2020

Accepted: 2 February 2021

\begin{abstract}
Background - A common site of neuroendocrine tumors (NETs) is the rectum. The technique most often used is endoscopic mucosal resection with saline injection. However, deep margins are often difficult to obtain because submucosal invasion is common. Underwater endoscopic mucosal resection (UEMR) is a technique in which the bowel lumen is filled with water rather than air, precluding the need for submucosal lifting. Objective - This study aimed to evaluate the efficacy and safety of UEMR for removing small rectal neuroendocrine tumors (rNETs). Methods - Retrospective study with patients who underwent UEMR in two centers. UEMR was performed using a standard colonoscope. No submucosal injection was performed. Board-certified pathologists conducted histopathologic assessment. Results - UEMR for small rNET was performed on 11 patients (nine female) with a mean age of 55.8 years and 11 lesions (mean size $7 \mathrm{~mm}$, range 3-12 $\mathrm{mm}$ ). There were 9 ( $81 \%$ ) patients with G1 rNET and two patients with G2, and all tumors invaded the submucosa with only one restricted to the mucosa. None case showed vascular or perineural invasion. All lesions were removed en bloc. Nine (81\%) resections had free margins. Two patients had deep margin involvement; one had negative biopsies via endoscopic surveillance, and the other was lost to follow-up. No perforations or delayed bleeding occurred. Conclusion - UEMR appeared to be an effective and safe alternative for treatment of small rNETs without adverse events and with high en bloc and R0 resection rates. Further prospective studies are needed to compare available endoscopic interventions and to elucidate the most appropriate endoscopic technique for resection of rNETs.

Keywords - Neuroendocrine tumors; underwater endoscopic resection; rectal neuroendocrine tumors.
\end{abstract}

\section{INTRODUCTION}

Gastrointestinal neuroendocrine tumors (NETs) account for more than $60 \%$ of all NETs, with $12-36 \%$ of gastrointestinal NETs being rectal (rNETs), representing the third most common site involved.

rNETs are known to not be aggressive, with a 5-year survival rate of $88.3 \%$ for all stages ${ }^{(1,2)}$. .NETs smaller than $10 \mathrm{~mm}$ are considered good candidates for endoscopic treatment because fewer than $2 \%$ and $1 \%$ are associated with lymph node and distant metastases, respectively ${ }^{(2)}$. Nonetheless, several studies have suggested that rNETs from $10 \mathrm{~mm}$ to $15 \mathrm{~mm}$ in size might be treated endoscopically if they did not have a high mitotic count and proliferation or lymph node metastasis ${ }^{(2)}$.

Surgical resection represents the treatment of choice for rNETs. However, small rNETs confined to the mucosa or submucosa (i.e., American Joint Committee on Cancer - T1 tumors) are currently treated with endoscopic resection because of their low risk of metastasis $^{(3)}$.

Regardless, for G1 rNETs $<20 \mathrm{~mm}$, there is still a debate about the best method of removal because endoscopic resection of rNETs results in good long-term outcomes.

In a recent study involving 727 patients with rNET, lymph node and distant metastases were present in $1.1 \%$ of lesions $\leq 10 \mathrm{~mm}$ and in $6.6 \%$ of lesions $11-19 \mathrm{~mm}$. Metastasis negatively impacted the 5-year survival of these patients ( $78 \%$ vs $100 \%, P<0.001$ ), but endoscopic resection performed as well as radical surgery did, with $100 \%$ in 5 -year survival ${ }^{(4)}$.

Many techniques for rNET endoscopic resection have been described, including polypectomy, endoscopic mucosal resection (EMR), EMR with band ligation, endoscopic submucosal dissection (ESD), and even transanal endoscopic microsurgery ${ }^{(5)}$. The technique most commonly applied is EMR with saline injection. However, because submucosal invasion of these tumors occurs very early, obtaining deep free margins with the EMR technique might be challenging, and it is not uncommon to achieve only exiguous or even involved deep margins.

Underwater endoscopic mucosal resection (UEMR) is an alternative to EMR and represents a simple and inexpensive new technique that has been used for the treatment of polyps and flat lesions ${ }^{(6-8)}$. Kawaguti et al. ${ }^{(7)}$ first reported the UEMR technique for resection of $\mathrm{rNETs}^{(9)}$.

The underwater method likely increases the buoyancy of submucosal tumors, which lift and float away from the muscularis propria. Additionally, deflating the air loosens the mucosal folds, which creates pseudopedicles that allow the operator to more easily snare the lesions ${ }^{(9)}$.

Therefore, we aimed to evaluate the efficacy and safety of using the UEMR technique for the resection of small rNETs.

Declared conflict of interest of all authors: none

Disclosure of funding: no funding received

${ }^{1}$ Universidade de São Paulo, Faculdade de Medicina, Instituto do Câncer do Estado de São Paulo (ICESP), Serviço de Endoscopia, São Paulo, SP, Brasil. ${ }^{2}$ Fleury Medicina e Saúde, São Paulo, SP, Brasil. Corresponding author: Lara Meireles Azeredo Coutinho. E-mail: larameirelescoutinho@gmail.com 


\section{METHODS}

This is a retrospective study performed at two institutions, Instituto do Câncer do Estado de São Paulo (ICESP) and Fleury Medicina e Saúde (FMS), between June 2015 and October 2018. The records of 11 consecutive patients with $\mathrm{rNETs} \leq 12 \mathrm{~mm}$ in diameter who underwent UEMR were evaluated (FIGURE 1). The main outcome of this study was to assess the efficacy and safety of using the UEMR technique for resecting small rNETs.

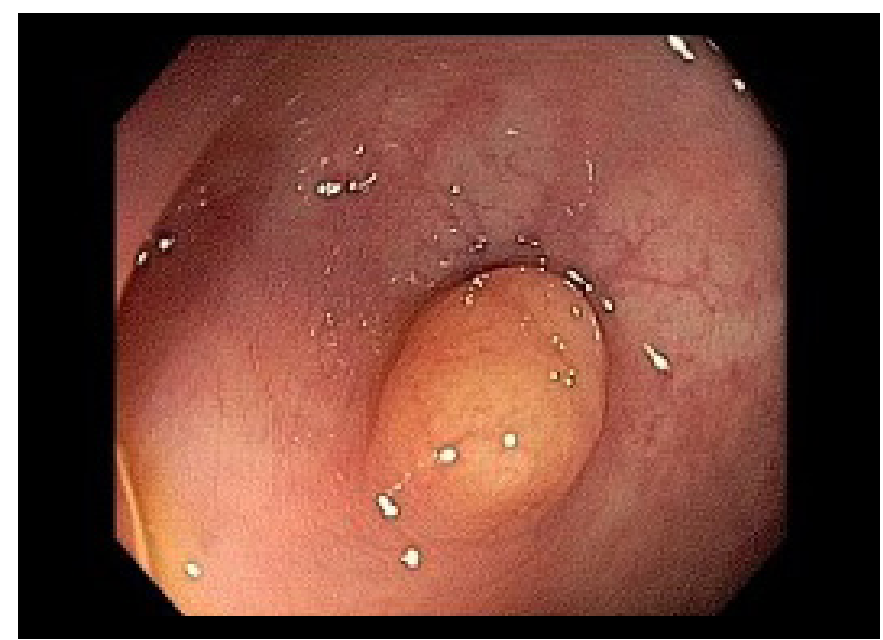

FIGURE 1. rNETs: rectal neuroendocrine tumors.

All procedures were performed using a standard colonoscope (CF-H180 Olympus ${ }^{\circledR}$, Tokyo, Japan - ICESP and 600HL Fujinon ${ }^{\circledR}$, Tokyo, Japan) without a distal cap. Electrical cutting and coagulation was carried out using a VIO 300D (ERBE ${ }^{\circledR}$ Elektromedizin, Tübingen, Germany) power source. Patients were sedated with fentanyl, midazolam and propofol. Hyoscine $\left(\right.$ Buscopan $\left.^{\circledR}\right)$ was used to reduce peristalsis. The UEMR procedure employed a polypectomy snare (Captivator II, Boston $13 \mathrm{~mm}$, United States of America). Insufflation was switched off. The colon lumen was entirely deflated, and water (at room temperature) was infused using an irrigation pump until complete filling of the lumen was achieved. All gas pockets in the operative field were evacuated. No submucosal injection was performed ${ }^{(10)}$. The lesion was then snared, together with the surrounding normal mucosa, and resected (FIGURE 2). All patients consumed a soft meal after the procedure, and no hospitalization was required for any of them.

Argon plasma was not used in any procedure. No clip was needed to close the mucosal defect. The wound was observed underwater and then with air insufflation. Complications were assessed by reviewing medical records.

All resected lesions were sent to a board-certified pathologist for histopathology (histologic grade, status of resected margins, depth of invasion, lymphovascular invasion).

\section{RESULTS}

A total of 11 patients (TABLE 1), nine (81\%) of whom were female, with a mean age 55.8 years (range from 30 to 73 years) and 11 lesions (mean size $7 \mathrm{~mm}$, range from 3 to $12 \mathrm{~mm}$ ) underwent UEMR for small rNETs. Three patients were referred for resection of a lesion previously identified, whereas the finding was incidental

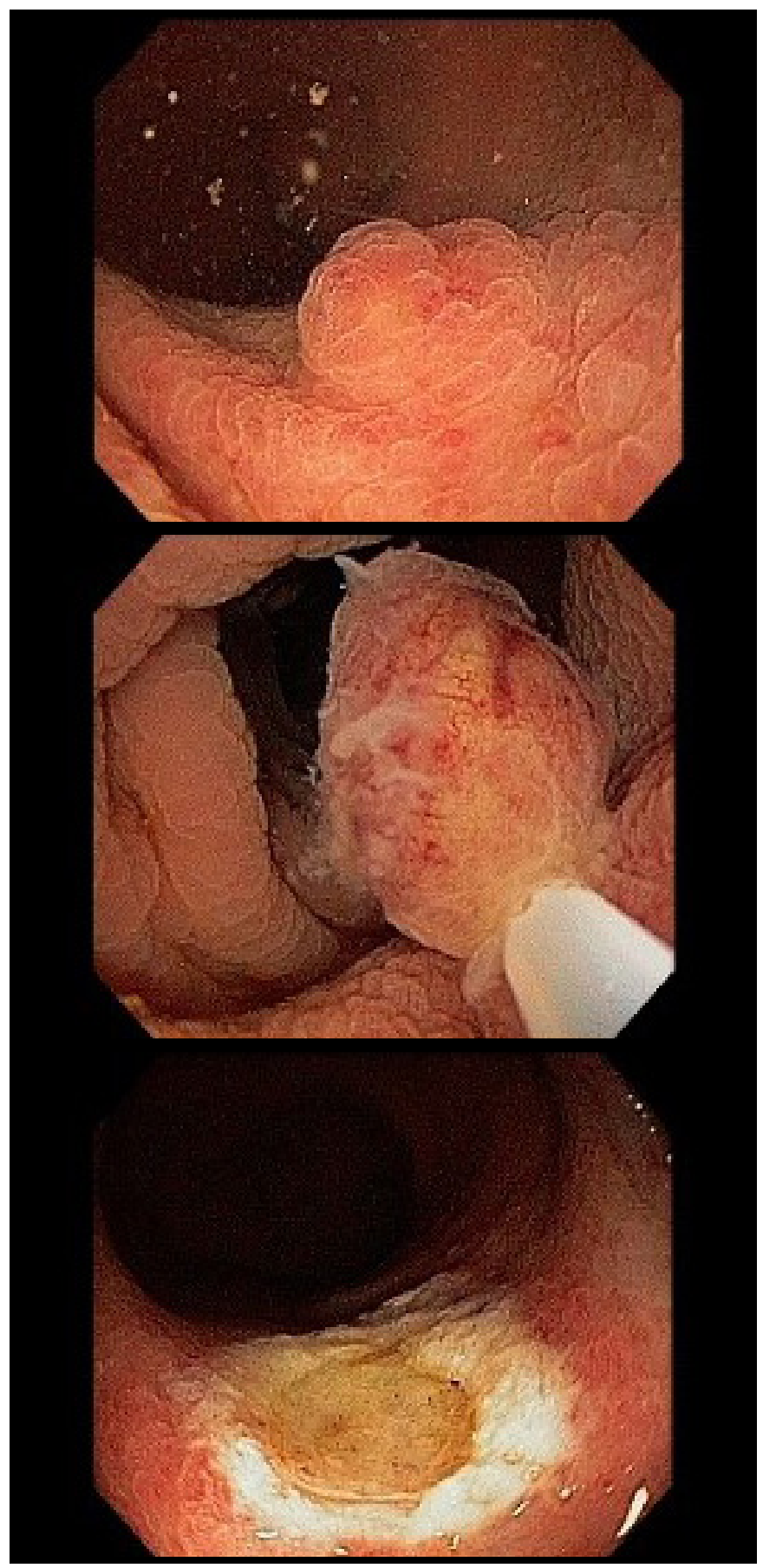

FIGURE 2. Underwater endoscopic mucosal resection procedure.

in eight patients. There were nine (81\%) patients with G1 rNET and two with G2; all lesions infiltrated the submucosa, except for one that was restricted to the mucosa. No vascular or perineural invasion was detected. All lesions were removed en bloc. A total of nine $(81 \%)$ resections had free margins. Two patients had deep margin involvement: one had negative biopsies via endoscopic surveillance (60 months follow up); the other was lost to followup. No perforation or delayed bleeding occurred. The follow-up time ranged from 5 to 60 months. Only one patient was lost to 
TABLE 1. Patients characteristics and procedure outcomes.

\begin{tabular}{|c|c|c|c|c|c|c|c|c|c|}
\hline Case & Age (years) & Sex & $\begin{array}{l}\text { Depth of } \\
\text { invasion }\end{array}$ & Size $(\mathrm{cm})$ & $\begin{array}{c}\text { Vessel } \\
\text { invasion }\end{array}$ & Lesions margins & Classification & Perforation & $\begin{array}{c}\text { Follow-up } \\
\text { (months) }\end{array}$ \\
\hline 2 & 66 & M & submucosa & 0.6 & No & Free & G1 & No & 32 months \\
\hline 4 & 54 & F & submucosa & 0.8 & No & Free & G2 & No & 60 months \\
\hline 5 & 54 & $\mathrm{~F}$ & submucosa & 1 & No & Free & G1 & No & 27 months \\
\hline 6 & 72 & M & submucosa & 1.2 & No & Free & G1 & No & 10 months \\
\hline 8 & 73 & $\mathrm{~F}$ & submucosa & 0,3 & No & Free & G1 & No & 33 months \\
\hline 9 & 35 & $\mathrm{~F}$ & submucosa & 0.5 & No & Free & G1 & No & 24 months \\
\hline 10 & 51 & F & submucosa & 0.6 & No & Deep involvement & G1 & No & Lost follow-up \\
\hline 11 & 61 & $\mathrm{~F}$ & submucosa & 0.7 & No & Free & G1 & No & 5 months \\
\hline
\end{tabular}

follow-up. Both patients with G2 had endoscopic surveillance with biopsies of the scar without any sign of neoplasia, and both have been out patient follow-up for 60 months ( 5 years) without evidence of disease.

\section{DISCUSSION}

Endoscopic resection should be considered for most rNETs $<10 \mathrm{~mm}$ and can be considered for rNETs varying in size from 10 $\mathrm{mm}$ to $12 \mathrm{~mm}$ if favorable findings are present at pre-interventional evaluation and by histopathological analyses ${ }^{(6)}$.

In this study, UEMR for rNETs G1 $\leq 12 \mathrm{~mm}$ in diameter achieved a $100 \%$ en bloc resection rate and an $81 \% \mathrm{R} 0$ resection rate, with no adverse events. In a series including 6 rNETs $<10$ mm, Yamashina et al. ${ }^{(9)}$ also obtained a $100 \%$ en bloc resection rate and an $83 \% \mathrm{R} 0$ rate.

It has been suggested that ESD results in a higher en bloc resection rate than does EMR (UEMR, ESMR-L, polypectomy). ESD was applied for the first time to remove rectal carcinoids in the study of Naoyuki et al. ${ }^{(1)}$ in which 20 rNETs measuring $10 \mathrm{~mm}$ or less in diameter were treated. En bloc resection was achieved for all lesions. In the current series, complete resection was achieved for $90 \%(18 / 20)$. The median time for ESD treatment in their study was $45 \mathrm{~min}$ (range, 20-140 $\mathrm{min}$; mean, $54.5 \mathrm{~min}$ ), and there was one case of perforation ${ }^{(11)}$.

Among 31 patients subjected to ESD and 62 subjected to EMR, Park et al. ${ }^{(12)}$ reported that the resection time was longer in the ESD group (11.4 \pm 3.7 minutes vs $4.2 \pm 3.2$ minutes, $P<0.001)$. The en bloc resection rate was 100\% (31 of 31) in the ESD group and $95.2 \%$ (59 of 62) in the EMR group $(P<0.213)$, and the R0 rate was $90.3 \%$ (28 of 31) in the ESD group and $71.0 \%$ (44 of 62 ) in the EMR group $(P=0.035)$. Suspected perforation occurred in one ESD patient (3.2\%) and in one EMR patient (1.6\%), and both patients were successfully managed by conservative measures. Immediate bleeding occurred in one ESD patient $(3.2 \%)$ and in four EMR patients $(6.5 \%)$; all instances of bleeding were controlled endoscopically. There was no local recurrence or distant metastasis in any patient in either group during the follow-up period ${ }^{(12)}$. Lee et al. ${ }^{(13)}$ also compared the safety and efficacy of ESD versus EMR for rNETs. For 74 lesions, 28 were resected by EMR, and 46 were removed by ESD. The endoscopic complete resection rate was significantly higher in the ESD group (46 lesions, 100\%) than in the EMR group (25 lesions, $89.3 \%)(P=0.049)$, and the R0 rate was also higher in the ESD group (38 lesions, 82.6\%) than in the
EMR group (18 lesions, 64.3\%). However, this difference was not significant $(P=0.07)$, and the overall complication rate did not differ ${ }^{(13)}$. In the above-mentioned series, conventional EMR or ESMR-L was employed.

In a recent study, published in $2020^{(14)}$ the authors compared UEMR and ESD in 115 patients (36 patients underwent UEMR and 79 patients underwent ESD). The study reported that there was no difference of $\mathrm{R} 0$ resection rates in both groups, however, the procedure time was significantly shorter in the UEMR group. There was no statistically significant difference of adverse events, however ESD group had 2.5\% of adverse events and UEMR group had none. Overall, ESD requires high levels of expertise and has a longer procedure time. Comparatively, UEMR seems to be technically simpler, less invasive and faster.

Concerning long-term results, Sekiguchi et al. ${ }^{(15)}$ evaluated the outcomes of patients with rNETs treated by polypectomy/endoscopic mucosal resection $(n=3)$, endoscopic submucosal resection with a ligation device (ESMR-L) $(n=83)$, and ESD $(n=4)$. The median tumor size was $5 \mathrm{~mm}$, and eight lesions were $10 \mathrm{~mm}$ or larger. This study achieved en bloc resection for all lesions treated by ESMR-L, except for two. En bloc resection with tumor-free margins (R0) was achieved for all but three lesions. Furthermore, none of the patients developed local recurrence or metastasis during the follow-up period of 67.5 months (range, 12.2-175.2 months $)^{(15)}$. Mashimo et al. ${ }^{(16)}$ also retrospectively analyzed endoscopic resection with a ligation device (ESMR-L) for rNETs $<10$ $\mathrm{mm}$ in diameter; the sizes of resected tumors ranged from 2 to 12 $\mathrm{mm}$ in diameter. Mashimo et al. ${ }^{(16)}$ reported similar results, with ESMR-L providing an overall high complete resection rate of $95.2 \%(60 / 63)$. In that study, margin involvement after ESMR-L was found for three lesions, which were histopathologically considered incomplete resections. No additional treatment but careful followup was conducted, and no local recurrence or distant metastasis was detected within a short period after ESMR-L. Moreover, no major complications occurred ${ }^{(16)}$.

The main limitation of this study is the small sample size and the retrospective, uncontrolled design. However, to our knowledge, this is the second largest series ever published. In conclusion, the results of small series suggest that UEMR may be an effective and safe alternative method for treating small rNETs without adverse events and with high en bloc and $\mathrm{R} 0$ resection rates.

Further prospective studies are needed to compare available endoscopic techniques to elucidate the most appropriate management for rNETs. 


\section{Authors' contribution}

Coutinho LMA statistical analysis and writing of text. Lenz L, Kawaguti FS, Martins BC and Rodrigues R data collection and writing of text. Baba E, Gusmon C, Andrade G and Simas $\mathrm{M}$ data collection. Safatle-Ribeiro A, Maluf-Filho F and Ribeiro Junior U text review.

\section{Orcid}

Lara Meireles Azeredo Coutinho: 0000-0002-9059-0512.

Luciano Lenz: 0000-0002-7945-8158.
Fabio S Kawaguti: 0000-0002-6709-9979.

Bruno Costa Martins: 0000-0002-0282-0753.

Elisa Baba: 0000-0001-7261-9054.

Carla Gusmon: 0000-0003-3803-3417.

Gustavo Andrade: 0000-0002-7926-9373.

Marcelo Simas: 0000-0002-4601-7276.

Adriana Safatle-Ribeiro: 0000-0001-7686-8859.

Fauze Maluf-Filho: 0000-0001-8875-420X.

Rodrigo Rodrigues: 0000-0003-2788-2667.

Ulysses Ribeiro Jr: 0000-0003-1711-7347.

Coutinho LMA, Lenz L, Kawaguti FS, Martins BC, Baba E, Gusmon C, Andrade G, Simas M, Safatle-Ribeiro A, Maluf-Filho F, Rodrigues R, Ribeiro Junior U. Ressecção endoscópica sob imersão d'água de pequenos tumores neuroendócrinos retais. Arq Gastroenterol. 2021;58(2):210-3.

RESUMO - Contexto - Um local comum de tumores neuroendócrinos (TNEs) é o reto. A técnica mais utilizada é a ressecção endoscópica da mucosa com injeção de solução salina. No entanto, as margens profundas costumam ser difíceis de ressecar porque a invasão da submucosa é comum. A ressecção endoscópica sob imersão d'água (RESI) é uma técnica em que o lúmen intestinal é preenchido com água em vez de ar, evitando a necessidade de elevação submucosa. Objetivo - Este estudo teve como objetivo avaliar a eficácia e segurança da RESI para a remoção de pequenos TNEs retais (rTNEs). Métodos - Estudo retrospectivo com pacientes que realizaram RESI em dois centros. RESI foi realizada usando um colonoscópio padrão. Nenhuma injeção submucosa foi realizada. Patologistas certificados conduziram avaliação histopatológica. Resultados - RESI foi realizada para pequenos rTNEs em 11 pacientes (nove mulheres) com média de idade de 55,8 anos e 11 lesões (tamanho médio de 7 mm, variando de 3-12 $\mathrm{mm})$. Havia $9(81 \%)$ pacientes com G1 rTNEs e dois pacientes com G2, sendo que todos os tumores invadiam a submucosa sendo apenas um restrito a mucosa. Nenhum caso mostrou invasão vascular ou perineural. Todas as lesões foram removidas em bloco. Nove (81\%) ressecções tiveram margens livres. Dois pacientes tiveram envolvimento de margens profundas; um teve biópsias negativas por meio de vigilância endoscópica e o outro perdeu o acompanhamento. Não ocorreram perfurações ou sangramento tardios. Conclusão - A RESI parece ser uma alternativa eficaz e segura para o tratamento de pequenos rTNEs sem eventos adversos e com altas taxas de ressecção em bloco e R0. Mais estudos prospectivos são necessários para comparar as intervenções endoscópicas disponíveis e para elucidar a técnica endoscópica mais adequada para ressecção de rTNEs.

Palavras-chave - Tumores neuroendócrinos; ressecção endoscópica sob imersão d'água; tumores neuroendócrinos retais.

\section{REFERENCES}

1 Murai K, Imai K, Hotta K, Ito S, Yamaguchi Y, Ono H. A 10-year history of a diminutive rectal neuroendocrine tumor. Intern Med. 2018;57:677-9.

2 Yang DH, Park Y, Park SH, Kim KJ, Ye BD, Byeon JS, et al. Cap-assisted EMR for rectal neuroendocrine tumors: Comparisons with conventional EMR and endoscopic submucosal dissection (with videos). Gastrointest Endosc. 2016;83:1015-22.

3 Kwak MS, Chung SJ, Yang JI, Im JP, Park MJ, Lee C, et al. Long-term outcome of small, incidentally detected rectal neuroendocrine tumors removed by simple excisional biopsy compared with the advanced endoscopic resection during screening colonoscopy. Dis Colon Rectum. 2018;61:338-46.

4 Ngamruengphong S, Kamal A, Akshintala V, Hajiyeva G, Hanada Y, Chen YI, et al. Prevalence of metastasis and survival of 788 patients with T1 rectal carcinoid tumors. Gastrointest Endosc. 2019;89:602-6.

5 Wu J, Srirajaskanthan R, Ramage J. Rectal neuroendocrine tumor. Dig Endosc. 2014;26:532-3.

6 Rodrigues A, Castro-Pocas F, Pedroto I. Neuroendocrine rectal tumors: Main features and management. GE Portugese J Gastroenterol. 2015;22:213-20.

7 Kawaguti FS, de Oliveira JF, da Costa MB, et al. Underwater endoscopic resection of a neuroendocrine rectal tumor. Endoscopy. 2015;47 (Suppl 1 UCTN): E513-4

8 Jeon JH, Cheung DY, Lee SJ, Kim HJ, Kim HK, Cho HJ, et al. Endoscopic resection yields reliable outcomes for small rectal neuroendocrine tumors. Dig Endosc. 2014;26:556-63.

9 Yamashina T, Tumura T, Maruo T, Matsumae T, Yoshida H, Tanke G, et al. Underwater endoscopic mucosal resection: A new endoscopic method for resection of rectal neuroendocrine tumor grade 1 (carcinoid) $</=10 \mathrm{~mm}$ in diameter. Endosc Int Open. 2018;6:E111-4.
10 Binmoeller KF, Weilert F, Shah J, Bhat Y, Kane S. "Underwater" EMR withou submucosal injection for large sessile colorectal polyps (with video). Gastrointest Endosc. 2012;75:1086-91.

11 Yamaguchi N, Hajime I, Hitoshi N, Fukuda E, Ishii H, Nakamura T, et al. Endoscopic submucosal dissection for rectal carcinoid tumors. Surg Endosc. 2010;24:504-8

12 Park HW, Byeon JS, Park YS, Yang DH, Yoon SM, Kim KJ, et al. Endoscopic submucosal dissection for treatment of rectal carcinoid tumors. Gastrointest Endosc. 2010;72:143-9.

13. Lee DS, Jeon SW, Park SY, Jung MK, Cho CM, Tak WY, et al. The feasibility of endoscopic submucosal dissection for rectal carcinoid tumors: comparison with endoscopic mucosal resection. Endoscopy. 2010;42:647-51.

14 Park SS, Han KS, Kim B, Kim BC, Hong CW, Sohn DK, Chang HJ. Comparison of underwater endoscopic mucosal resection and endoscopic submucosal dissection of rectal neuroendocrine tumors (with videos). Gastrointest Endosc. 2020;91:1164-71.

15 Sekiguchi M, Sekine S, Sakamoto T, Otake Y, Nakajima T, Matsuda T, et al Excellent prognosis following endoscopic resection of patients with rectal neuroendocrine tumors despite the frequent presence of lymphovascular invasion. J Gastroenterol. 2015;50:1184-9.

16 Mashimo Y, Matsuda T, Uraoka T, Saito Y, Sano Y, Fu K, et al. Endoscopic submucosal resection with a ligation device is an effective and safe treatment for carcinoid tumors in the lower rectum. J Gastroenterol Hepatology. 2008; 23:218-21. 